\title{
Perfil metabólico protéico e taxas de concepção de vacas de corte mantidas em pastagem natural ou suplementadas com farelo de trigo com ou sem uréia
}

\author{
Protein metabolic profile and conception rate of beef cows kept on nature pasture or supplemented with wheat \\ meal, with or without urea
}

\author{
Luiz Antero de Oliveira Peixoto ${ }^{1}$ Ivan Luiz Brondani ${ }^{2}$ José Laerte Nörnberg $^{3}$ João Restle ${ }^{4}$ \\ Dari Celestino Alves Filho ${ }^{2}$ Marceli Pazini ${ }^{5}$ Marlei Terezinha Coradini ${ }^{6}$ \\ Cássio Vieira Marques dos $\operatorname{Santos}^{6}$
}

\section{RESUMO}

Este trabalho teve o objetivo de avaliar o perfil metabólico protéico de vacas de corte suplementadas ou não do parto ao desmame, comparando os teores de nitrogênio uréico, no leite e no sangue, com a taxa de concepção das vacas e os tratamentos. Foram utilizadas 115 vacas dos grupos genéticos Charolês $(C)$, Nelore $(N)$ e suas respectivas cruzas. A idade das vacas variou de 3 a 13 anos, sendo divididas em três classes de idade: jovens, adultas e velhas, tendo sido avaliadas do parto até o desmame dos bezerros, aos 63 dias pós-parto. Foi verificada interação $(P<0,05)$ entre tratamento e grupo genético para o teor de nitrogênio uréico sérico (NUS). As vacas suplementadas com farelo de trigo mais uréia apresentaram teor de NUS superior aos das não suplementadas $e$ ao das suplementadas somente com farelo de trigo $(18,19 \mathrm{vs}$ 14,54 e $12,48 \mathrm{mg} d L^{-1}$, respectivamente). Os teores de albumina sérica e nitrogênio uréico do leite (NUL) não diferiram $(P>0,05)$ entre tratamentos e períodos. A taxa de concepção das vacas não foi influenciada pelos teores de NUS e NUL nem pela suplementação.

Palavras-chave: albumina sérica, Charolês, Nelore, nitrogênio uréico sérico, nitrogênio uréico do leite, perfil metabólico.

\section{ABSTRACT}

This study evaluated the protein metabolic profile of beef cows supplemented or not, from calving to weaning. comparing urea nitrogen values, from milk and blood serum, with conception rate. 115 beef cows from Charolais, Nellore and its crosses were used. Cow's age ranged between 3 and 13 years old, and separate into three age classes: young, adult and old, being evaluate since calving until weaning, at day 63 postpartum. There was an interaction $(P<0.05)$ between treatment and genetic group for serum urea nitrogen (SUN) level, being supplemented cows with urea at wheat meal presented SUN level higher than cows not supplemented and supplemented only with wheat meal (18.19 vs 14.54 e $12.48 \mathrm{mg} . d L^{-1}$, respectively). Serum albumin and milk urea nitrogen $(M U N)$ levels didn't differ $(P>0.05)$ between treatment and period. SUN and MUN levels and supplementation didn't influence conception rate.

Key words: serum albumin, Charolais, Nellore, serum urea nitrogen, milk urea nitrogen, metabolic profile.

\section{INTRODUÇÃO}

Devido aos baixos índices reprodutivos atingidos na bovinocultura de corte, com uma taxa de natalidade que chega a apenas 55\% (ANUALPEC, 2003), ultimamente os produtores têm manejado os animais de modo mais intensificado. Entretanto, os custos para melhorar esses índices reprodutivos podem ser muito elevados, dependendo do manejo utilizado. Uma das formas para se diminuir os custos com alimentação é adicionar uréia à dieta das vacas de cria, a qual é uma fonte barata e concentrada de nitrogênio para a produção de proteína pelos microorganismos ruminais.

${ }^{1}$ Programa de Pós-graduação em Zootecnia (PPGZ), Universidade Federal de Santa Maria (UFSM). Rua Enedir Souza de Lima, 131/ 02,85660-000, Dois Vizinhos, PR, Brasil. E-mail: laope@pop.com.br. Autor para correspondência.

${ }^{2}$ Departamento de Zootecnia, UFSM, RS, Brasil.

${ }^{3}$ Departamento de Tecnologia e Ciência dos Alimentos, UFSM, RS, Brasil.

${ }^{4}$ Departamento de Produção Animal da Universidade Federal de Goiás (UFG), Goiás, GO, Brasil.

${ }^{5}$ Medicina Veterinária, UFSM, RS, Brasil.

${ }^{6}$ Autônomo. 
A avaliação do perfil metabólico em vacas de corte é uma abordagem recente, que vem despertando o interesse de pesquisadores. Segundo CONTRERAS (2000), o perfil metabólico pode colaborar no estudo do balanço nutricional dos rebanhos, uma vez que, em algumas situações, os desbalanços nutricionais podem influenciar nas concentrações sangüíneas de alguns metabólitos.

Nitrogênio uréico do sangue (NUS) e albumina sérica são os principais metabólitos utilizados para monitorar o status nutricional protéico em bovinos; mais recentemente, também tem sido utilizado o nitrogênio uréico do leite (NUL), que é uma maneira menos estressante e invasiva de monitorar as vacas, além de apresentar uma alta correlação com NUS (MOORE \& VARGA, 1996). A uréia sérica equilibra-se rapidamente entre os compartimentos líquidos do organismo e também no leite. Admite-se que a concentração de NUL reflete a concentração de NUS (BRODERICK \& CLAYTON, 1997), além da concentração de uréia no leite ser um bom indicador do metabolismo protéico em vacas (ROSELER et al., 1993; HOF et al., 1997; OLIVEIRA et al., 2001).

Os objetivos deste estudo foram avaliar o perfil metabólico protéico de vacas de corte suplementadas ou não do parto ao desmame e comparar os teores de nitrogênio uréico, no leite e no sangue, com a taxa de concepção das vacas.

\section{MATERIAL E MÉTODOS}

O experimento foi desenvolvido no Setor de Bovinocultura de Corte do Departamento de Zootecnia da Universidade Federal de Santa Maria (UFSM) e ocorreu nos meses de setembro de 2003 a maio de 2004.

Foram utilizadas 115 vacas com cria ao pé provenientes do mesmo rebanho, sendo 17 vacas da raça Charolês $(\mathrm{C}), 19$ da raça Nelore $(\mathrm{N}), 29$ vacas mestiças filhas de touros Charolês e 50 vacas mestiças filhas de touros Nelore. Durante o período do pósparto ao desmame (aos 63 dias), as vacas e os bezerros permaneceram em pastagem natural e receberam os seguintes tratamentos: PN - 36 vacas com cria ao pé exclusivamente em pastagem natural; FTR - 41 vacas com cria ao pé em pastagem natural, com suplementação diária de $0,7 \%$ do peso vivo de farelo de trigo; FTRU 38 vacas com cria ao pé em pastagem natural, com suplementação diária de $0,7 \%$ do peso vivo de farelo de trigo + uréia $\left(12,5 \mathrm{~g} 100 \mathrm{~kg}^{-1}\right.$ peso vivo). A disponibilidade média de forragem da pastagem natural durante o período experimental foi de $2.790 \mathrm{~kg} \mathrm{MS} \mathrm{ha}^{-1}$, contendo um teor médio de $7,5 \%$ de proteína bruta e
$72,54 \%$ de fibras em detergente neutro. A suplementação foi oferecida diariamente à tarde, sendo que somente as vacas tinham acesso aos suplementos. A quantidade de suplemento era atualizada diariamente, de acordo com o número de vacas por tratamento e o peso vivo de cada uma ao ingressar no experimento.

A idade das vacas variou de 3 a 13 anos e, à medida que as vacas iam parindo, foram distribuídas entre os tratamentos de acordo com a ordem de parição e idade da vaca.

As coletas de sangue e do leite das vacas foram realizadas aos 21, 42 e 63 dias pós-parto. O método utilizado para a coleta do leite dos animais foi o direto, através da ordenha manual. Foi realizada a ordenha total de dois quartos do úbere, um quarto anterior e outro posterior. Do leite retirado de cada vaca, foi coletada uma amostra de $50 \mathrm{~mL}$ para análise do nitrogênio uréico e da proteína láctea, sendo que imediatamente após a ordenha as amostras foram colocadas em frascos plásticos e congeladas até o momento da análise laboratorial.

As amostras de sangue das vacas foram coletadas na veia coccígea em tubos Vacutainer ${ }^{\circledR}$ de $4 \mathrm{~mL}$ devidamente identificados. Após isso, era realizada a centrifugação a 2.500 rpm por 15 minutos para a obtenção do soro sangüíneo. O soro obtido foi armazenado em tubos ependorfes de $2 \mathrm{~mL}$ e conservado a $-20^{\circ} \mathrm{C}$ até o momento da análise bioquímica. Foram analisados os indicadores bioquímicos do status nutricional protéico através da análise sérica de albumina e nitrogênio uréico. As amostras foram analisadas no NIDAL - UFSM, mediante a utilização de kits laboratoriais ${ }^{\mathrm{a}}$ para medida de nitrogênio uréico no leite, no soro sangüíneo e para albumina sérica.

O delineamento experimental foi inteiramente casualizado, num arranjo fatorial $3 \times 3 \times 4$ (3 tratamentos, 3 períodos e 4 grupos genéticos), no qual cada vaca compunha uma repetição. Os resultados obtidos foram submetidos à análise de variância, seguidos do Teste F, e as médias comparadas pelo teste de Tukey ao nível de $10 \%$ de significância. A ordem de parição e a idade da vaca foram utilizadas como covariáveis. As análises dos dados foram realizadas utilizando-se o pacote estatístico SAS (2001). O modelo matemático utilizado foi o seguinte:

$\mathrm{Y}_{\mathrm{ijkkm}}=\mu+\mathrm{OP}_{\mathrm{i}}+\mathrm{IV}_{\mathrm{j}}+\mathrm{S}_{\mathrm{k}}+\mathrm{GG}_{1}+\mathrm{PER}_{\mathrm{m}}+$
$(\mathrm{S} * \mathrm{GG})_{\mathrm{kl}}+(\mathrm{S} * \mathrm{PER})_{\mathrm{km}}+(\mathrm{GG} * \mathrm{PER})_{\mathrm{lm}}+\stackrel{\circ}{\mathrm{ijklm}}$
em que: $\mathrm{Y}_{\mathrm{ijklm}}=$ variáveis dependentes $\mu=$ média geral em que: $Y_{\mathrm{ijklm}}=$ variáveis dependentes; $\mu=$ média geral
de todas as observações; $\mathrm{OP}_{\mathrm{i}}=$ efeito da covariável ordem de nascimento do bezerro de ordem "i"; $I_{\mathrm{j}}=$ efeito da covariável classe de idade da vaca de ordem “j, sendo $1=$ jovens, $2=$ adultas e $3=$ velhas; $S_{k}=$ efeito da k-ésima suplementação, sendo $1=\mathrm{PN}, 2=\mathrm{kTR}$ e 
3=FTRU; $\mathrm{GG}_{1}=$ efeito do grupo genético de ordem "l”, sendo $1=$ Charolês, $2=$ Nelore, $3=\mathrm{CN}$ e $4=\mathrm{NC}$; PER $_{\mathrm{m}}=$ efeito do m-ésimo período; $(\mathrm{S} * \mathrm{GG})_{\mathrm{kl}}=$ interação entre a k-ésima suplementação e o l-ésimo grupo genético; $(\mathrm{S} * \mathrm{PER})_{\mathrm{km}}=$ interação entre a k-ésima suplementação e o m-ésimo período; $(\mathrm{GG} * \mathrm{PER})_{\mathrm{lm}}=$ interação entre o lésimo grupo genético e o m-ésimo período; åijk $\mathrm{k}_{\mathrm{lm}}=$ erro aleatório associado à cada observação.

Não foi verificada interação entre suplementação, grupo genético das vacas e períodos, de maneira que esta foi retirada do modelo. A taxa de parição foi analisada pelo teste Qui-quadrado.

\section{RESULTADOS E DISCUSSÃO}

A figura 1 apresenta as médias de NUS, NUL e albumina sérica, de acordo com o tratamento. Houve diferença significativa entre os tratamentos somente para os teores de NUS. Os valores médios encontrados para albumina e NUS $\left(2,36\right.$ e $14,98 \mathrm{mg} \cdot \mathrm{dL}^{-1}$, respectivamente) ficaram dentro dos valores preconizados por GONZÁLEZ (2000) para bovinos de corte $\left(<3,0 \mathrm{e}<15 \mathrm{mg} \cdot \mathrm{dL}^{-1}\right.$, respectivamente).

Os teores médios de albumina, diferentemente do que ocorreu com o NUS, não apresentaram diferença $(\mathrm{P}>0,10)$ entre os tratamentos. GREGORY \& SIQUEIRA (1983) e GONZÁLEZ et al. (1993) haviam citado valores superiores de albumina sérica $\left(>2,8 \mathrm{mg} \mathrm{dL}^{-1}\right)$ para vacas de corte, inclusive associando baixos teores com infertilidade.

A diferença verificada para NUS em favor dos animais alimentados com uréia já era esperada, uma vez que o período de avaliação foi curto e a uréia demonstra o estado protéico do animal em curto prazo, enquanto a albumina o demonstra em longo prazo (PAYNE \& PAYNE, 1987). CARROL et al. (1988), trabalhando com vacas alimentadas com baixa (13\%) ou alta (20\%) concentração de proteína bruta na dieta, também encontraram valores maiores para NUS em favor das vacas alimentadas com maior concentração de proteína bruta $\left(24,5\right.$ vs. $\left.10,0 \mathrm{mg} \mathrm{dL}^{-1}\right)$.

O NUL, apesar de ter apresentado uma correlação de $49 \%$ com NUS, não apresentou diferença entre os tratamentos $(\mathrm{P}>0,10)$. $\mathrm{O}$ teor médio de NUL ficou em 14,0 $\mathrm{mg} \mathrm{dL}^{-1}$, dentro dos padrões preconizados por MOORE \& VARGA (1996), que citaram valores entre $10 \mathrm{e} 14 \mathrm{mg} \mathrm{dL}^{-1}$, permitindo ainda uma variação de $4 \mathrm{mg} \mathrm{dL}^{-1}$.

A figura 2 apresenta os teores de NUS, NUL e albumina sérica conforme o período de avaliação. Não houve diferença significativa entre os períodos (P>0,10) para o teor de albumina sérica.

PAYNE \& PAYNE (1987) sugeriram que para detectar mudanças significativas na concentração sérica de albumina é necessário o período de um mês, devido à baixa velocidade de síntese e de degradação desta proteína em ruminantes. Já CONTRERAS (2000) citou que, após o parto, as vacas tendem a diminuir a albuminemia basicamente por dois fatores: em primeiro lugar, porque a demanda de aminoácidos para a síntese de proteína no leite reduz a síntese de outras proteínas e, por isso, a concentração de albumina diminui na medida em que a lactação avança; e, em seguida ligar, porque ocorre uma redução da capacidade de síntese no fígado, devido ao acúmulo de gordura que este órgão sofre no início da lactação.

Ainda na figura 2, verifica-se que houve variação nos teores de NUS e NUL $(\mathrm{P}<0,10)$, com os valores decrescendo do $21^{\circ}$ ao $42^{\circ}$ dia pós-parto e voltando a subir na análise do63dia. MOORE \&VARGA(1996) citaram que a tendência para o NUS é de que haja um rápido acréscimo durante o primeiro mês após o parto, crescendo mais lentamente do primeiro ao quinto mês de lactação; relataram também que a concentração de NUS pode ser difícil de ser interpretada, quando os valores mudam rapidamente durante o primeiro mês pós-parto.

Figura 1 - Teores médios de nitrogênio uréico do sangue (NUS), de nitrogênio uréico do leite (NUL) e de albumina sérica de acordo com os tratamentos. 


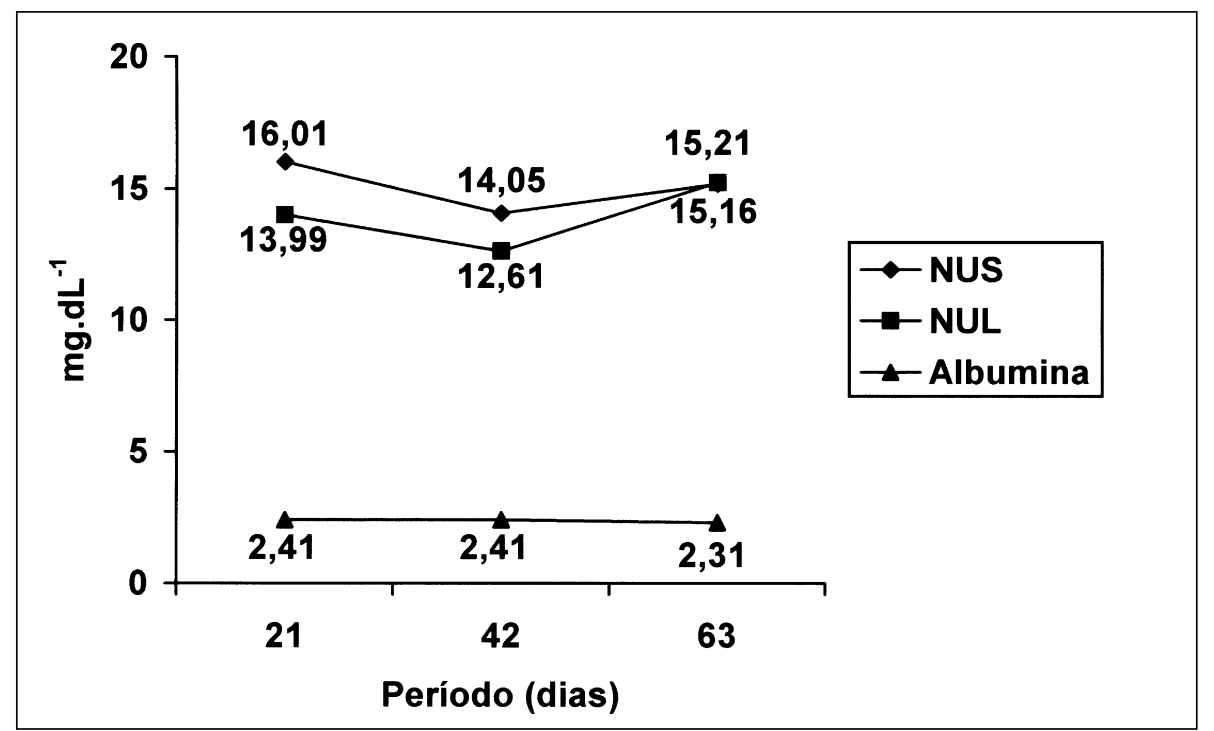

Figura 2 - Variações de nitrogênio uréico do sangue (NUS), de nitrogênio uréico do leite (NUL) e de albumina sérica de acordo com o período.

A tabela 1 apresenta a relação entre NUS no desmame e a taxa de concepção das vacas de acordo com os tratamentos. Não foi verificada diferença significativa $(\mathrm{P}>0,10)$ para a taxa da concepção em vacas com nível de NUS maior ou menor que $15 \mathrm{mg} \mathrm{dL}^{-1}$. FERGUSON \& CHALUPA (1989) relataram que a concentração de NUS em vacas não é influenciada somente pelo teor de proteína bruta na dieta, mas também pela degradabilidade da proteína, pelo consumo energético e pela taxa de degradação, pelo tempo da coleta após a alimentação e pelos métodos de suplementação.

$\mathrm{O}$ valor de $15 \mathrm{mg} \mathrm{dL}^{-1}$ como interseção para a taxa de concepção foi utilizado tanto para o NUS como para o NUL, pois o teor médio para ambas as variáveis foi próximo a $15 \mathrm{mg} \mathrm{dL}^{-1}$. FERGUSON et al. (1993) verificaram que vacas diminuíam a porcentagem de gestação com níveis de NUS acima de $20 \mathrm{mg} \mathrm{dL}^{-1}$. Do mesmo modo, BUTLER (1998) verificou um teor de NUS acima de $19 \mathrm{mg} \mathrm{dL}^{-1}$, associado à redução da concentração plasmática de progesterona e à alteração do $\mathrm{pH}$ do ambiente uterino, relacionando-os como principais causas de redução da fertilidade em vacas leiteiras no início da lactação.

Com relação aos tratamentos, apesar de não ter sido verificada diferença $(\mathrm{P}>0,10)$, as vacas alimentadas com farelo de trigo mais uréia com teor de NUS inferior a $15 \mathrm{mg} . \mathrm{dL}^{-1}$ apresentaram taxa de concepção $50 \%$ superior às vacas dos demais tratamentos. Já quando o teor de NUS foi maior que $15 \mathrm{mg} \mathrm{dL}^{-1}$, a taxa de concepção das vacas do tratamento FTRU foi $67 \%$ superior às vacas não suplementadas. Este resultado mostra que vacas de corte suplementadas com uréia podem apresentar um bom d e s e m p e n h o reprodutivo, ao contrário do que se observa em vacas leiteiras de alta produção. Esta diferença numérica proporciona um maior número de bezerros nascidos e, consequentemente, um excelente auxílio ao produtor na melhoria dos índices reprodutivos do rebanho de cria.

Conforme apresentado na tabela 2, a taxa de concepção das vacas não foi influenciada $(\mathrm{P}>0,05)$ pelo teor de NUL, independentemente do tratamento a que foram submetidas. Para vacas de corte, os teores de NUS e NUL parecem não influenciar os parâmetros reprodutivos, já que não são animais de alta produção como as vacas de leite, além de as vacas deste trabalho terem recebido um teor de proteína bruta na dieta que não foi capaz de elevar os níveis de NUS e NUL acima de $19 \mathrm{mg} \mathrm{dL}^{-1}$.

Esses resultados levam a crer que a suplementação de vacas de corte no pós-parto com dietas que contenham uréia na sua formulação não possui efeito negativo sobre o desempenho reprodutivo destes animais. Em termos práticos, caso o produtor disponha de piquetes suficientes, que proporcionem a adaptação das vacas à alimentação com uréia, o desempenho reprodutivo pode ser ainda melhor, com diminuição do intervalo entre o parto e o primeiro cio e aumento da taxa de gestação.

Tabela 1 - Relação entre nitrogênio uréico do sangue (NUS) no desmame e taxa de concepção das vacas de acordo com os tratamentos.

\begin{tabular}{lcccc}
\hline \multirow{2}{*}{ Teor de NUS } & \multicolumn{3}{c}{ Tratamento } & \\
\cline { 2 - 4 } & PN & FTR & FTRU & \\
\hline & \multicolumn{3}{c}{----- Taxa de gestação (\%) } & ----- \\
& 40,00 & 41,18 & 60,71 & 52,00 \\
$<15 \mathrm{mg} \cdot \mathrm{dL}^{-1}$ & 46,43 & 62,50 & 77,78 & 57,38 \\
Média & 45,45 & 53,66 & 64,86 & \\
\hline
\end{tabular}

$\mathrm{P}>0,05$

$\mathrm{PN}$ - Pastagem natural

FTR - Pastagem natural + farelo de trigo

FTRU - Pastagem natural + farelo de trigo + uréia

Ciência Rural, v.36, n.6, nov-dez, 2006. 
Tabela 2 - Relação entre nitrogênio uréico do leite (NUL) no desmame e taxa de concepção das vacas, de acordo com os tratamentos.

\begin{tabular}{|c|c|c|c|c|}
\hline \multirow{2}{*}{ Teor de NUS } & \multicolumn{3}{|c|}{ Tratamento } & \multirow{2}{*}{ Média } \\
\hline & PN & FTR & FTRU & \\
\hline & \multicolumn{4}{|c|}{----- Taxa de gestação (\%) ----- } \\
\hline$>15 \mathrm{mg} \cdot \mathrm{dL}^{-1}$ & 45,45 & 56,25 & 64,71 & 56,82 \\
\hline$<15 \mathrm{mg} \cdot \mathrm{dL}^{-1}$ & 45,45 & 52,00 & 65,00 & 53,73 \\
\hline Média & 45,45 & 53,66 & 64,86 & \\
\hline
\end{tabular}

$\mathrm{P}>0,05$

$\mathrm{PN}$ - Pastagem natural

FTR - Pastagem natural + farelo de trigo

FTRU - Pastagem natural + farelo de trigo + uréia

A relação entre os níveis de NUL e a reprodução em vacas também tem demonstrado diferenças entre as literaturas. Segundo RAJALASCHULTZ et al. (2001), vacas com teor médio de NUL abaixo de $10 \mathrm{mg} \mathrm{dL}^{-1}$ têm 2,4 vezes mais chances de confirmar a prenhez do que aquelas com NUL acima de 15,4mg dL ${ }^{-1}$. MOORE \& VARGA (1996) também citam que altos níveis de NUS e NUL podem reduzir a eficiência reprodutiva, possivelmente pelo desbalanço energético produzido. Porém, WENNINGER (1994) afirma que concentrações de NUL entre 15 e $25 \mathrm{mg} \mathrm{dL}^{-1}$ são ótimas para o trato reprodutivo, tanto para diminuir intervalos entre partos como para melhorar taxas de concepção.

\section{CONCLUSÕES}

A introdução de uréia na dieta de vacas de corte proporciona um aumento no teor do nitrogênio uréico do sangue, aumento este que não modifica a taxa de concepção das vacas. Tanto o nitrogênio uréico do sangue como o nitrogênio uréico do leite podem ser utilizados na avaliação da taxa de concepção de vacas de corte, segundo os resultados obtidos.

\section{FONTES DE AQUISIÇÃO}

a. Kits fornecidos gratuitamente por Doles Reagentes e Equipamentos para Laboratório Ltda ${ }^{\circledR}$.

\section{REFERÊNCIAS}

ANUALPEC. Anuário estatístico da produção animal. FNP. São Paulo: Camargo Soares, 2003. 400p.

BRODERICK, G.A.; CLAYTON, M.K. A statistical evaluation of animal and nutritional factors influencing concentrations of milk urea nitrogen. Journal of Dairy Science, v.80, p.29642971, 1997.
BUTLER, W.R. Effect of protein nutrition on ovarian and uterine physiology in dairy cattle. Journal of Dairy Science, v.81, n.9, p.2533-2539, 1998.

CARROL, D.J. et al. Influence of protein intake and feeding strategy on reproductive performance of dairy cows. Journal of Dairy Science, v.71, p.3470-3481, 1988.

CONTRERAS, P.A. Indicadores do metabolismo protéico utilizados nos perfis metabólicos de rebanhos. In: GONZÁLEZ, F.H.D. et al. (Eds). Perfil metabólico em ruminantes: Seu uso em nutrição e doenças nutricionais. Porto Alegre: UFRGS, 2000. p.23-30.

FERGUSON, J.D.; CHALUPA, W. Symposium: interactions of nutrition and reproduction. Journal of Dairy Science, v.72, p.746-766, 1989 .

FERGUSON, J.D. et al. Serum urea nitrogen and conception rate: the usefulness of test information. Journal of Dairy Science, v.76, p.3742-3746, 1993.

GONZALEZ, F.H.D. et al. Efeito da condição corporal em novilhas mestiças sobre a fertilidade e os níveis sanguíneos de glicose, albumina e progesterona pós-serviço. Revista Brasileira de Zootecnia, v.22, n.3, p.439-444, 1993.

GONZALEZ, F.H.D. Uso do perfil metabólico para determinar o status nutricional em gado de corte. In: GONZÁLEZ, F.H.D. et al. (Eds). Perfil metabólico em ruminantes: Seu uso em nutrição e doenças nutricionais. Porto Alegre: UFRGS, 2000. p.63-74.

GREGORY, R.M.; SIQUEIRA, A.J.S. Fertilidade de vacas de corte com diferentes níveis de albumina sérica em aleitamento permanente e interrompido. Revista Brasileira de Reprodução Animal, v.7, n.1, p.47-50, 1983.

HOF, G. et al. Milk urea nitrogen as a tool to monitor the protein nutrition of dairy cows. Journal of Dairy Science, v.80, p.3333-3340, 1997

MOORE, D.A.; VARGA, G. BUN and MUN: urea nitrogen testing in dairy cattle. Compendium Continuing Education Practicing Veterinary, v.18, p.712-721, 1996.

OLIVEIRA, A.S. et al. Produção de proteína microbiana e estimativas das excreções de derivados de purinas e de uréia em vacas lactantes alimentadas com rações isoprotéicas contendo diferentes níveis de compostos nitrogenados não-protéicos. Revista Brasileira de Zootecnia, v.30, n.5, p.1621-1629, 2001 .

PAYNE, J.M.; PAYNE, S. The metabolic profile test. Oxford: Oxford University, 1987.

RAJALA-SCHULTZ, P.J. et al. Association between milk urea nitrogen and fertility in Ohio dairy cows. Journal of Dairy Science, v.84, n.2, p.482-489, 2001.

ROSELER, D.K. et al. Dietary protein degradability effects on plasma and milk urea nitrogen and milk nonprotein nitrogen in Holstein cows. Journal of Dairy Science, v.76, p.525-534, 1993.

SAS, Institute Incorporation. SAS language reference. Version 6. Cary, NC, 2001. 1042p.

WENNINGER, A. Urea and acetone content in milk as indicators for nutritionally caused fertility disorders of dairy cows. Deutsch Tierärtzl Wochenschr, v.101, n.4, p.152157,1994 